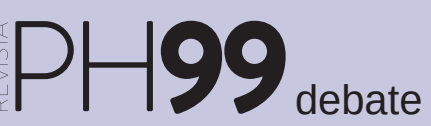

a debate Patrocinio, mecenazgo, crowdfunding ¿compromiso social o marketing interesado?

| coordina Ana Isabel Velasco Rebollo

\title{
El mecenazgo de lo intangible: patrimonio cultural inmaterial y patrocinio en la Semana Santa de Baena (Córdoba)
}

\author{
Alejandro Ruiz Salas | arquitecto \\ María Isabel Sabio Cabrera | arquitecta \\ URL de la contribución <www.iaph.es/revistaph/index.php/revistaph/article/view/4574>
}

El patrimonio inmaterial ha cobrado una gran relevancia en la última década, especialmente a raíz de la Convención para la Salvaguardia del Patrimonio Cultural Inmaterial aprobada por la UNESCO en 2003 y que, en su artículo 2.1, nos muestra que se entiende como tal "los usos, representaciones, expresiones, conocimientos y técnicas -junto con los instrumentos, objetos, artefactos y espacios culturales que les son inherentes- que las comunidades, los grupos y en algunos casos los individuos reconozcan como parte integrante de su patrimonio cultural", además de indicar que "se transmite de generación en generación, es recreado constantemente por las comunidades y grupos en función de su entorno, su interacción con la naturaleza y su historia, infundiéndoles un sentimiento de identidad y continuidad y contribuyendo así a promover el respeto de la diversidad cultural y la creatividad humana" (CONVENCIÓN, 2003); es decir, que se podría considerar que su importancia reside en su propia inmaterialidad, en su transmisión y en su forma de adaptarse tanto al medio como a los nuevos tiempos. Aunque por propia definición, se reconoce que existen bienes materiales y espacios culturales que son inseparables de este tipo de patrimonio, por lo que nos surge una pregunta básica: ¿qué ocurre con la conservación de todos aquellos bienes materiales asociados a lo intangible?

En el caso de la Semana Santa, como una de las tradiciones de mayor envergadura en gran parte de los municipios de toda España, nos encontramos que el propietario de la mayor parte de los bienes culturales asociados a dicha tradición es la Iglesia, a través de las hermandades y cofradías, pero que el propio pueblo ha asumido como parte de su identidad cultural, responsabilizándose en algunos casos de la financiación necesaria para la recuperación de estos bienes. Aunque este hecho, que en un principio está pensado para obtener resultados positivos -ya sea desde el punto de vista físico al recuperar parte de la imaginería, o desde el punto de vista inmaterial, para facilitar la transmisión de sus valorespuede tornarse en desastre, ya que en algunas ocasiones la identidad cultural puede convertirse en moneda de cambio en el momento de decidir sobre cómo intervenir sobre el patrimonio cultural, siendo en lo que respecta a la Semana Santa, tallas e imágenes con siglos de antigüedad. Por este motivo se puede considerar que es lícito que el pueblo se preocupe por su herencia cultural e incluso que haga aportaciones para que ese legado no se pierda, pero siempre se realicen desde el sentido común y acompañados de profesionales que realicen las apropiadas labores de conservación y restauración.

Al hilo de esta reflexión, vamos recurrir a un ejemplo que se podría considerar de buenas prácticas en cuestión de mecenazgo, y que es el Plan Director de Restauración y

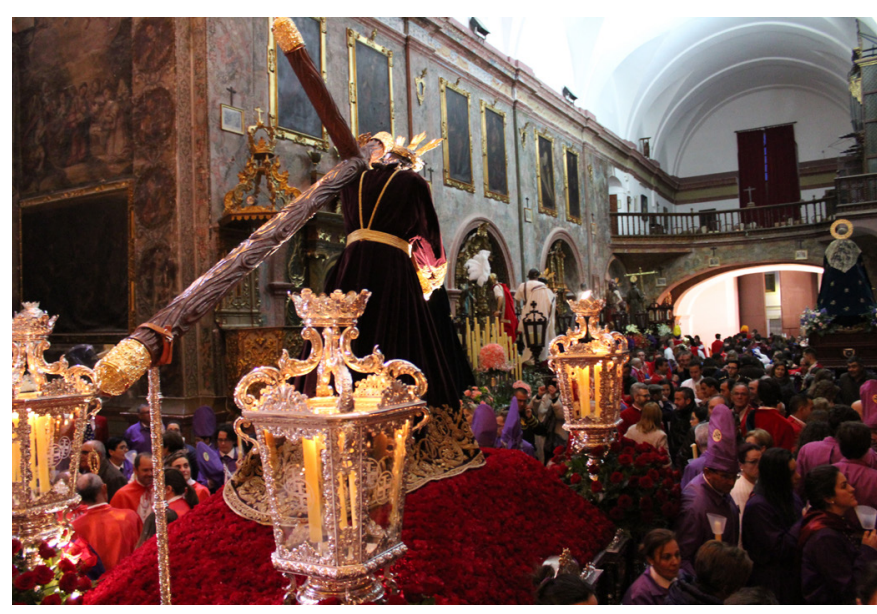

Viernes Santo (iglesia de San Francisco de Baena) | foto Adela Ruiz Rodríguez 
Conservación del Patrimonio de la Cofradía de Nuestro Padre Jesús Nazareno de Baena (Córdoba), cuya Semana Santa está declarada de Interés Turístico Nacional -actualmente la Administración Local está trabajando para obtener la declaración de Interés Turístico Internacionaly cuyas tamboradas fueron declaradas patrimonio cultural inmaterial por la UNESCO en el año 2018, junto con otros 16 municipios localizados en Aragón, Castilla-La Mancha, Comunidad Valenciana y Murcia (EXPEDIENTE, 2018).

La iniciativa de este Plan Director nació de la Cofradía de Nuestro Padre Jesús Nazareno -cuyo origen se remonta a 1589 (EXPÓSITO, 1999)-, y se presentó en 2018 suponiendo una apuesta a largo plazo -para cumplirlo en un período de 10 años- e incluyendo la intervención sobre 19 bienes culturales de diversa índole (se plantean intervenciones de distinto grado, siendo en el menor de los casos actuaciones de conservación preventiva y, en casos más graves, restauración), y todo ello asumido por una cuota anual financiada por todos los hermanos integrantes. Previamente a este Plan, presentado en agosto de 2018, la Cofradía realizó un inventario de todos sus bienes y un informe de su estado de conservación, el cual permitió establecer el orden de las intervenciones, habiendo conseguido desde su aprobación, la recuperación de 4 bienes culturales y la adquisición de uno nuevo. Las intervenciones fueron las siguientes: la recuperación de la imagen de Jesús Nazareno -una talla de madera que se adquirió entre 1701-1733 y que realizó Miguel de Perea-; la tareas necesarias para la conservación de la cruz de madera perteneciente a Jesús Nazareno -también tallada y adquirida en 1508-; la adquisición de una nueva cruz de madera ahuecada; las tareas de conservación de la imagen de María Magdalena -una tallada de madera policromada, adquirida en 1926 y cuyo autor es Enrique Bellido-; y por último, las tareas necesarias de conservación de la Virgen de los Dolores - una talla de madera policromada adquirida entre los años 17011750 y cuyo autor es desconocido, aunque atribuido a la Escuela granadina- (EXPÓSITO, 1999); habiendo sido todas las tareas de conservación y restauración llevadas a cabo por Salvador Guzmán Moral, doctor en Bellas Artes y conservador-restaurador.
El desarrollo de este Plan plantea algunos interrogantes en lo que respecta al patrocinio de este tipo de tradiciones, sobre todo en los temas que tienen que ver con su tutela, ya que sería necesario establecer algunas directrices que no se deberían sobrepasar, pero que en este caso se supo manejar a través de la realización de un inventario y un informe del estado de conservación de las piezas. El patrimonio cultural inmaterial compone la identidad de cualquier pueblo y está interiorizado por parte de individuos y comunidades (PLAN, 2015), por lo que actos de participación social como este Plan Director donde el protagonista es la propia comunidad, nos lleva a ser conscientes de que estas tradiciones no se van a perder gracias al esfuerzo y al sentimiento de arraigo de sus habitantes, lo que nos permite concluir que el mecenazgo puede ser una herramienta clave tanto en la conservación de los bienes culturales como en la transmisión de valores inmateriales, lo que en definitiva supone que la herencia cultural de todos los pueblos sea capaz de sobrevivir al tiempo.

\section{BIBLIOGRAFÍA}

- CONVENCIÓN para la Salvaguardia del Patrimonio Cultural Inmaterial (2003). En Textos fundamentales de la Convención para la Salvaguardia del Patrimonio Cultural Inmaterial de 2003 [en línea]. París: UNESCO, Sección del Patrimonio Cultural Inmaterial, Sector de Cultura, 2012 <http://www.culturaydeporte. gob.es/dam/jcr:f77f0454-13c3-4de9-8c13-b0cd250cf1e0/ textos-fundamentales.pdf> [Consulta: 21/01/2020]

- EXPEDIENTE de candidatura. Las tamboradas, repiques rituales de tambores (2018). En UNESCO, Patrimonio Cultural Inmaterial <https://ich.unesco.org/es/RL/las-tamboradas-repi ques-rituales-de-tambores-01208> [Consulta: 21/01/2020]

- EXPÓSITO, F. M. (1999) Semana Santa de Baena. Historia de una devoción popular. Baena: Gráficas Cañete, 1999, pp. 89-135.205-209

- ARANDA, J. (1995) Historia de la Semana Santa de Baena durante los siglos XVI al XX. Baena: Andalucía Gráfica, 1995, pp. 23-27.123-136

- PLAN nacional de Salvaguarda del Patrimonio Cultural Inmaterial (2015) Madrid: Ministerio de Educación, Cultura y Deporte, Secretaría General Técnica, Subdirección General de Documentación y Publicaciones, 2015 